\title{
Talk and Die Syndrome: A Narrative Review
}

Ariana A Chacón-Aponte ${ }^{1}$, Érika A Durán-Vargas², Jaime A Arévalo-Carrillo ${ }^{3}$, Amit Agrawal ${ }^{4}$, Ivan D Lozada-Martinez ${ }^{5}$, Tariq Janjua ${ }^{6}$, Luis R Moscote-Salazar ${ }^{7}$, Ved P Maurya ${ }^{8}$, Rakesh Mishra ${ }^{9}$, Mohammed M Al-Salihi $^{10}$, Moshiur Rahman $^{11}$

\section{Abstract}

The level of consciousness following head trauma generally correlates with the overall prognosis of an individual. It is a consensus that following a head injury, patients able to talk (Glasgow coma scale verbal of 3 or 4) perform well over time. However, there is a subset of patients who suddenly deteriorates and succumb despite talking after trauma. Such an event was labeled as "talk and die". This review aims to summarize the published literature on talk and die syndrome, considering the relevance of this condition, especially in Latin America and the Caribbean, where there are high rates of traumatic brain injury.

Keywords: Brain concussion, Brain contusion, Talk and die syndrome, Traumatic brain injuries.

\section{Resumen}

O nível de consciência após um traumatismo craniano geralmente determina o prognóstico geral de um indivíduo. Os pacientes que são notados num estado de conversação (Glasgow coma scale verbal de 3 o 4) após uma sobrecarga de impacto são considerados num consenso geral para terem um bom desempenho ao longo do tempo. Existe um subconjunto de doentes que apesar de falarem após um trauma se deterioram subitamente e sucumbem, tal evento foi rotulado como "falar e morrer". Considerando a relevância desta condição, especialmente na América Latina e nas Caraíbas, onde existem altas taxas de traumatismos cerebrais. O objectivo desta revisão é resumir a literatura publicada sobre a síndrome de falar e morrer.

Palabras clave: Lesões cerebral traumáticas, Concussão cerebral, Contusão cerebral, Síndrome da Fala e da Morte.

Panamerican Journal of Trauma, Critical Care \& Emergency Surgery (2021): 10.5005/jp-journals-10030-1322

\section{INTRODUCTION}

The level of consciousness following head trauma generally correlates with the overall prognosis of an individual. Those patients able to talk (Glasgow coma scale verbal of 4) are expected on consensus, to perform well over time. There is, however, a subset of patients who, despite talking after trauma, deteriorate suddenly and succumb; such an event was labeled as "talk and die" by Reilly et al. in the year 1975. ${ }^{1}$ The term "talk and die" is not just a fancy combination of words, but it represents an entire event that comes into attention in its dismal outcome. The "talk and die" or "talk and deteriorate" events represent the gradual increase in intracranial pressure (ICP) following a significant blow to the head resulting in a malignant rise in ICP. This elevated ICP results in significant impairment of sensorium and sets a chain of events leading to death. The talk phase following head trauma may range from minutes to several hours and even days. This phase represents a relatively better appearance of the individual, which is labeled as Lucid interval. $^{2-4}$

Reilly et al. introduced the term talk and die to discuss a subset of patient populations treated initially as mild head injury but having sudden deterioration. With the introduction of this phenomenon to the neurosurgical fraternity, there was a rapid surge in reporting such events in the form of case reports and case series. Considering the relevance of this condition, especially in Latin America and the Caribbean with high rates of traumatic brain injury, this review aims to summarize the published literature on talk and die syndrome.

\begin{abstract}
${ }^{1-3}$ Department of Medicine, Colombian Clinical Research Group in Neurocritical Care, University of Pamplona, Cúcuta, Colombia

${ }^{4}$ Department of Neurosurgery, All India Institute of Medical Sciences, Bhopal, Madhya Pradesh, India

5,7Department of Medicine, Medical and Surgical Research Center, University of Cartagena, Cartagena, Colombia; Latin American Council of Neurocritical Care, Cartagena, Colombia; Globan Neurosurgery Committee, World Federation of Neurosurgical Societies

${ }^{6}$ Department of Intensive Care, Regions Hospital, Minnesota, USA

${ }^{8}$ Department of Neurosurgery, Sanjay Gandhi Postgraduate Institute of Medical Sciences, Lucknow, Uttar Pradesh, India

${ }^{9}$ Department of Neurosurgery, Institute of Medical Sciences, Banaras Hindu University, Varanasi, Uttar Pradesh, India

${ }^{10}$ Department of Medicine, University of Baghdad, Baghdad, Iraq

${ }^{11}$ Department of Neurosurgery, Holy Family Red Crescent Medical College, Dhaka, Bangladesh
\end{abstract}

Corresponding Author: Ariana A Chacón-Aponte, Department of Medicine, Colombian Clinical Research Group in Neurocritical Care, University of Pamplona, Cúcuta, Colombia, Phone: +91 3013763329 , e-mail: Arianachacon2@gmail.com

How to cite this article: Chacón-Aponte AA, Durán-Vargas ÉA, ArévaloCarrillo JA, et al. Talk and Die Syndrome: A Narrative Review. Panam J Trauma Crit Care Emerg Surg 2021;10(2):78-81.

Source of support: Nil

Conflict of interest: None

(c) The Author(s). 2021 Open Access This article is distributed under the terms of the Creative Commons Attribution 4.0 International License (https:// creativecommons.org/licenses/by-nc/4.0/), which permits unrestricted use, distribution, and non-commercial reproduction in any medium, provided you give appropriate credit to the original author(s) and the source, provide a link to the Creative Commons license, and indicate if changes were made. The Creative Commons Public Domain Dedication waiver (http://creativecommons.org/publicdomain/zero/1.0/) applies to the data made available in this article, unless otherwise stated. 


\section{Factors Leading to Talk and Die SYNDROME}

There are many factors responsible for the rapid deterioration following a severe head injury. Talk and die syndrome is reported in all forms of head injuries, from sports-related trauma, assault, or as part of polytrauma. ${ }^{5,6}$ With the advancement of the automobile industry and other rapidly evolving technologies, trauma has emerged as an "epidemic" of the 21st century. Head injury contributes to about half of all deaths due to trauma.

A study showed that 211 out of 838 patients talked for some time before undergoing deterioration and culmination into a coma. In this study cohort, $80.6 \%$ had some form of hematoma, while there was no identifiable lesion on neuroimaging in $19.4 \%$ of the patients. ${ }^{7}$ Most often, the underlying cause of talk and die syndrome is an underlying bleed which causes death. About $2.6 \%$ of all deaths due to head injury involves the talk and die phenomenon, as mentioned by an Australian trauma center. ${ }^{8}$ Nearly $27-60 \%$ of all deaths are attributed to head injury., 90

\section{Clinical Presentation}

Most patients presented with a decreased level of consciousness but were able to talk in some form better than the V3 component of GCS, i.e., able to respond a least with inappropriate words. They were labeled as mild to moderate head injury with GCS ranging from 9 to 14. The radiology of these individuals demonstrates a hematoma, which may expand over time. Reilly et al. ${ }^{11}$ identified the practical limitations in uniform management of head trauma, which is in the form of demography, structural variations in the impact of head trauma, and clinical presentation over a wide range of time. ${ }^{11}$ CT scans have been considered a gold standard to detect the definite lesion responsible for neurological impairment, even in the range of millimeters.

Intracranial pressure monitoring, transcranial Doppler, and invasive monitoring in the form of Jugular venous oxygen saturation are the modalities to monitor these patients' clinical course. ${ }^{12}$ The available literature suggests the incidence of talk and die in the range of $2.4-7.8 \% .{ }^{13-15}$ Over the last decade, it was observed by Shibahashi et al. ${ }^{16}$ a reduction in in-hospital mortality. The observation reflects a strong possibility of a better outcome in these subsets of the patient population once the limiting factors related to adequate monitoring are eliminated. ${ }^{16}$ In the series published by Reilly et al., ${ }^{1,11}$ nearly $38 \%$ of patients suffered the talk and die syndrome following trauma. On the contrary, only $21 \%$ of head trauma patients died after an episode of lucid interval suggesting an early detection with the widespread availability of CT scan services, modifications in referral patterns, and better availability of therapeutic modalities. ${ }^{17}$

Lobato et al. ${ }^{18}$ found in their series of 838 patients with a severe head injury that one-fourth had talked for some time and then lapsed into a comatose state. They noticed that $55 \%$ of these patients were transferred to higher centers, and only $6 \%$ died. Intracranial mass lesion was present in $80 \%$ of the patient's cohort. There was a lack of association between length of time leading to deterioration or surgical intervention and subsequent mortality. ${ }^{18}$

Ratanalert and Phuenpathom ${ }^{15}$ noticed a reverse association between the time of surgery following trauma and clinical deterioration. In continuation of previous studies, a case series of 33 patients found no difference in the time from deterioration to surgical intervention between the groups of patients who talked and survived vs who talked and died. This finding was in conjunction with that of the report from National Traumatic Coma Bank. ${ }^{19}$

\section{Mechanism Involved}

In the initial paper on talk and die by Reilly et al., ${ }^{1}$ the verbal score of 3 or higher was considered a prerequisite to label the head trauma as mild head injury. ${ }^{1}$ With the advent of the GCS score to assess the level of consciousness as an objective finding in head trauma patients, the more important component "motor" score has taken precedence over the remaining two scores to predict the outcome. The verbal component is easily modifiable and leads to confusion regarding proper categorization of the injury severity. Because of the heterogeneity, Hsiang et al. ${ }^{20}$ subdivided the GCS score of 13-15 into mild head injury and high-risk mild head injury to correlate the clinical outcome. ${ }^{20}$

Being an ailment of advanced age, the cardiorespiratory impairment and intracranial hematoma due to anticoagulants was a common event in most of these patients. A significant difference was noticed in age and the coagulation profile between the patients who presented with hematoma and refractory elevated ICP. Damage to the hypothalamic-pituitary axis leads to the release of antidiuretic peptides, resulting in endocrine disturbances following head trauma and electrolyte disturbances aggravated further by the cerebral salt wasting and syndrome of inappropriate antidiuretic hormone release. ${ }^{21}$

The pathophysiology underlying this talk and die phenomenon lies in its nomenclature. The radiology and postmortem evaluation suggest definitive hematoma in the form of extradural hematoma, subdural hematoma, a contusion that resulted in the cascade of events resulting in deterioration after a brief interval of well-being or improvement. There have been events when there was a total absence of definitive structural changes, the following blow to the head, presenting a diagnostic dilemma for the investigating pathologist. ${ }^{22}$ The victims of this syndrome may deteriorate rapidly, leading to loss of consciousness, or they may remain alert, conversate, and even able to walk away from the site of trauma just before collapsing.

Malignant cerebral edema, traumatic pontomedullary disconnection, cardiac arrhythmias, and neurometabolic cascade following cerebral concussion or diffuse axonal injury (DAI) are the speculated events leading to the talk and die phenomenon. ${ }^{22}$

A concussion is the mildest form of cerebral trauma without definite structural changes, and the extreme degree results in DAI with objective changes in the neuronal morphology and their metabolism. Giza and Hovda ${ }^{23}$ proposed the consequences of the second impact following a concussion injury, resulting in aberration of neurotransmitter function and cellular death (Table 1). ${ }^{23}$ The alteration in cerebral glucose metabolism, abnormal calcium influx, and abnormalities in the $N$-methyl-D-aspartic acid (NMDA) receptor may be held responsible for the unfavorable outcomes. Patients dying of expanding intracerebral hematoma were old, in the eight decades of life. The height of the fall was no more than a meter, and the most common was intracerebral hematoma. ${ }^{27,28}$ Danne et al. ${ }^{29}$ and Havill et al. ${ }^{30}$ have shown that delays in transferring head injury patients from community hospitals to tertiary care centers result in a worse outcome. 
Table 1: Differential diagnosis between talk and die syndrome and second impact syndrome

\begin{tabular}{|c|c|c|}
\hline & Talk and die syndrome $e^{13,16}$ & Second impact syndrome $e^{24-26}$ \\
\hline Risk factors & $\begin{array}{l}\text { - } \text { Older age } \\
\text { - } \text { Male sex } \\
\text { - Higher injury severity score } \\
\text { - Lower Glasgow Coma Scale } \\
\text { score } \\
\text { - Comorbidities } \\
\text { - Hypotension on arrival } \\
\text { - Subdural hemorrhage, } \\
\text { - } \text { Contusion } \\
\text { Vault fracture }\end{array}$ & $\begin{array}{l}\text { Being exposed to a second traumatic brain injury after not having a full recovery } \\
\text { from a previous trauma }\end{array}$ \\
\hline Mechanism & $\begin{array}{l}\text { Malignant cerebral edema, trau- } \\
\text { matic pontomedullary discon- } \\
\text { nection, cardiac arrhythmias as } \\
\text { well as neurometabolic cascade } \\
\text { following cerebral concussion or } \\
\text { diffuse axonal injury (DAI) }\end{array}$ & $\begin{array}{l}\text { Increased glucose utilization combined with the injury-related decrease in rest- } \\
\text { ing cerebral blood flow creates an energy mismatch. All these changes require } \\
\text { time and energy for a return to normal neurotransmitter physiology. Generally, } \\
\text { this is thought to take about 7-10 days but may be longer in younger athletes. } \\
\text { Metabolic abnormalities after an initial concussion may leave the brain more } \\
\text { susceptible to further injury }\end{array}$ \\
\hline $\begin{array}{l}\text { Timing of } \\
\text { deterioration }\end{array}$ & 6-24 hours after the trauma & Rapid deterioration, leading to death within $2-5$ minutes after the second injury \\
\hline $\begin{array}{l}\text { Observable } \\
\text { intracranial pathology }\end{array}$ & $\begin{array}{l}\text { Subdural hematoma, epidural } \\
\text { hematoma, diffuse brain damage }\end{array}$ & $\begin{array}{l}\text { In a large amount of reported data, bilateral thin subdural hematomas have been } \\
\text { found, with subsequent herniation }\end{array}$ \\
\hline
\end{tabular}

\section{Management}

The cornerstone of management relies on the prevention of secondary injuries and hematoma progression following head trauma. According to the latest edition of the Brain Trauma Foundation guidelines, a stepwise escalation of medical management and therapeutic interventions is indicated. ${ }^{31}$ Tan et al. ${ }^{7}$ observed that outcome following head trauma is poor if a diagnosis is delayed, and even worse in patients with advanced age. Early identification and continuous monitoring should prevent the development and progression of secondary injuries and irreversible damage. ${ }^{10}$ Patients with intracerebral lesions need to be monitored in anticipation of possible expansion over hours or even days. Antiedema measures should be initiated to avoid the malignant or rapidly escalating event of raised ICP.

The features suggesting expanding intracerebral hematoma or increasing cerebral edema warrant a repeat CT scan at the earliest to document the increased size of the hematoma objectively. Measures to document continuously elevated ICP with the insertion of an ICP monitor should be of diagnostic as well as therapeutic application. ${ }^{32}$ Rapid surgical decompression in the event of clinical deterioration holds a vital role in the management algorithm. Surgical intervention is vital for all those patients who present with Cushing's reflex, suggesting elevated ICP, or the development of new motor deficit suggesting compression of the brainstem either in rostral or at the caudal aspect. ${ }^{24-26}$

\section{Conclusion}

The syndrome of talk and die is noticed mainly in head trauma patients, and most of them are in their latter half of life. Careful monitoring of patients having additional risk factors is mandatory for a favorable outcome. Even when all measures are appropriately instituted, there is a possibility of late events of re-bleeding or expansion of hematoma leading to a devastating outcome. The knowledge of stepwise escalation of medical and surgical intervention will bring a favorable outcome with available resources. Regular triage of the admitted patients leads to further stratification of the severity and upgradation of the treatment guidelines to tie over the unexpected outcome. Thorough knowledge of the causes must be taught to all, for the benefit of the patients and stress reduction of the professionals with medicolegal issues in such events. A regular update of the available literature plays a vital role in patient care and future research.

\section{References}

1. Reilly PI, Graham DI, Adams JH, et al. Patients with head injury who talk and die. Lancet 1975;2(7931):375-377. DOI: 10.1016/s01406736(75)92893-7.

2. Isayama K, Kobayashi S, Nakazawa S. Patients with severe head trauma who talk and deteriorate. Neurosurg Rev 1989;12(S-1):446-450. DOI: 10.1007/BF01790689.

3. Ramsay DA, Shkrum MJ. Homicidal blunt head trauma, diffuse axonal injury, alcohol intoxication, and cardiorespiratory arrest: a case report of a forensic syndrome of acute brainstem dysfunction. Am J Forensic Med Pathol 1995;16(2):107-114. DOI: 10.1097/00000433-19950600000004.

4. Cantu RC, Voy R. Second impact syndrome: a risk in any contact sport. Phys Sportsmed 1995;23(6):27-34. DOI: 10.1080/00913847.1995.11947799.

5. Milovanovic VA, DiMaio VJM. Death due to concussion and alcohol. Am J Forensic Med Pathol 1999;20(1):6-9. DOI: 10.1097/00000433199903000-00002.

6. Zink BJ, Feustel PJ. Effects of ethanol on respiratory function in traumatic brain injury. J Neurosurg 1995;82(5):822-828. DOI: 10.3171/ jns.1995.82.5.0822.

7. Tan JE, Ng I, Lim J, et al. Patients who talk and deteriorate: A new look at an old problem. Ann Acad Med Singapore 2004;33(4):489-493.

8. Sultan HY, Boyle A, Pereira M, et al. Application of the Canadian $\mathrm{CT}$ head rules in managing minor head injuries in a UK emergency department: implications for the implementation of the NICE guidelines. Emerg Med J 2004;21(4):420-425. DOI: 10.1136/ emj.2003.011353. 
9. Hodgson NF, Stewart TC, Girotti MJ. Autopsies and death certification in deaths due to blunt trauma: what are we missing? Can J Surg 2000;43(2):130-136.

10. Tien HC, Spencer F, Tremblay LN, et al. Preventable deaths from hemorrhage at a level I Canadian trauma center. J Trauma 2007;62(1):142-146. DOI: 10.1097/01.ta.0000251558.38388.47.

11. Reilly PL. Brain injury: the pathophysiology of the first hours. 'Talk and Die revisited'. J Clin Neurosci 220;8(5):398-403. DOI: 10.1054/ jocn.2001.0916.

12. Borrel B, What is "talk and die" syndrome? By Brendan Borrell. 2009. [Available at: https://www.scientificamerican.com/article/talk-anddie-richardson/].

13. Davis DP, Kene M, Vilke GM, et al. Head-injured patients who "talk and die": the San Diego perspective. J Trauma 2007;62(2):277-281. DOI: 10.1097/TA.0b013e31802ef4a3.

14. Goldschlager T, Rosenfeld JV, Winter CD. Talk and die' patients presenting to a major trauma centre over a 10 year period: a critical review. J Clin Neurosci 2007;14(7):618-623. DOI: 10.1016/j. jocn.2006.02.018.

15. Ratanalert S, Phuenpathom N. Management of head injury patients who talked and deteriorated. Surg Neurol 1990;34(1):27-29. DOI: 10.1016/0090-3019(90)90168-o.

16. Shibahashi K, Sugiyama K, Okura Y, et al. A multicenter retrospective cohort study of 'talk and die' after traumatic brain injury. World Neurosurg 2017;107:82-86. DOI: 10.1016/j.wneu.2017. 07.117.

17. Dunn LT, Fitzpatrick MO, Beard $D$, et al. Patients with a head injury who "Talk and Die" in the 1990s. J Trauma 2003;54(3):497-502. DOI: 10.1097/01.TA.0000030627.71453.CD.

18. Lobato RD, Rivas JJ, Gomez PA, et al. Head-injured patients who talk and deteriorate into coma: analysis of 211 cases studied with computerized tomography. J Neurosurg 1991;75(2):256-261. DOI: 10.3171/jns.1991.75.2.0256.

19. Marshall LF, Toole BM, Bowers SA. The national traumatic coma data bank, part 2: patients who talk and deteriorate-implications for treatment. J Neurosurg 1983;59(2):285-288. DOI: 10.3171/ jns.1983.59.2.0285.
20. Hsiang JN, Yeung T, Yu AL, et al. High-risk mild head injury. J Neurosurg 1997;87(2):234-238. DOI: 10.3171/jns.1997.87.2.0234.

21. Zafonte RD, Mann NR. Cerebral salt wasting syndrome in brain injury patients: a potential cause of hyponatremia. Arch Phys Med Rehabil 1997;78(5):540-542. DOI: 10.1016/s0003-9993(97)90173-8.

22. Veevers AE, Lawler W, Rutty GN. Walk and die: an unusual presentation of head injury. J Forensic Sci 2009;54(6):1466-1469. DOI: 10.1111/j.1556-4029.2009.01201.x.

23. Giza CC, Hovda DA. The neurometabolic cascade of concussion. J Athl Train 2001;36(3):228-235. DOI: 10.1227/NEU.0000000000000505.

24. May T, Foris LA, Donnally CJ. Second impact syndrome. $2020 \mathrm{Jul} \mathrm{7.} \mathrm{In:}$ StatPearls [Internet]. Treasure Island (FL): StatPearls Publishing; 2021. pp. 3-7.

25. Stovitz SD, Weseman JD, Hooks MC, et al. What definition is used to describe second impact syndrome in sports? A systematic and critical review. Curr Sports Med Rep 2017;16(1):50-55. DOI: 10.1249/ JSR.0000000000000326.

26. Engelhardt J, Brauge D, Loiseau H. Second impact syndrome. Myth or reality? Neurochirurgie 2021;67(3):265-275. DOI: 10.1016/ j.neuchi.2019.12.007.

27. Galbraith S. Head injuries in the elderly. Br Med J (Clin Res Ed) 1987;294(6568):325. DOI: 10.1136/bmj.294.6568.325.

28. Jennett B. Epidemiology of head injury. Arch Dis Child 1998;78(5): 403-406. DOI: 10.1136/adc.78.5.403.

29. Danne P, Brazenor G, Cade R, et al. The major trauma management study: an analysis of the efficacy of current trauma care. Aust N Z J Surg 1998;68(1):50-57. DOI: 10.1111/j.1445-2197.1998.tb04637.x.

30. Havill J, Sleigh J, Kersel D, et al. Prehospital treatment of head injuriescan we do better? Emerg Med 1998;10(2):123-128. DOI: 10.1111/j.14422026.1998.tb00669.x.

31. Xi G, Keep RF, Hoff JT. Pathophysiology of brain edema formation. Neurosurg Clin N Am 2002;13(3):371-383. DOI: 10.1016/s10423680(02)00007-4.

32. Bratton SL, Chestnut RM, Ghajar J, et al. Guidelines for the management of severe traumatic brain injury. Vi. Indications for intracranial pressure monitoring. J Neurotrauma 2007;24(S-1): S37-S44. DOI: 10.1089/neu.2007.9990. 